\title{
Horseradish Peroxidase-Functionalized Gold Nanoconjugates for Breast Cancer Treatment Based on Enzyme Prodrug Therapy
}

\author{
Gema Vivo-Llorca ${ }^{1-3}$ \\ Ángela Morellá-Aucejo ${ }^{1-3}$ \\ Alba García-Fernández (iD) ${ }^{1-3}$ \\ Paula Díez ${ }^{1-4}$ \\ Antoni Llopis-Lorente ${ }^{1,5}$ \\ Mar Orzáez 3,6 \\ Ramón Martínez-Máñez ${ }^{1-4,7}$ \\ 'Instituto Interuniversitario de \\ Investigación de Reconocimiento \\ Molecular y Desarrollo Tecnológico \\ (IDM), Universitat Politècnica de \\ València, Universitat de València, \\ València, Spain; ${ }^{2} \mathrm{CIBER}$ de Bioingeniería, \\ Biomateriales y Nanomedicina (CIBER- \\ BBN), Madrid, Spain; ${ }^{3}$ Unidad Mixta UPV- \\ CIPF de Investigación de Mecanismos de \\ Enfermedades y Nanomedicina, Valencia, \\ Universitat Politècnica de València, \\ Centro de Investigación Príncipe Felipe, \\ València, Spain; ${ }^{4}$ Unidad Mixta de \\ Investigación en Nanomedicina \\ y sensores, Universitat Politènica de \\ València, Instituto de Investigación \\ Sanitaria la Fe, Valènica, Spain; \\ ${ }^{5}$ Department of Chemical Engineering \\ and Chemistry, Institute for Complex \\ Molecular Systems, Eindhoven University \\ of Technology, Eindhoven, The \\ Netherlands; ${ }^{6}$ Centro de Investigación \\ Príncipe Felipe, Laboratorio de Péptidos \\ y Proteínas, València, Spain; \\ ${ }^{7}$ Departamento de Química, Universitat \\ Politècnica de València, València, Spain
}

Correspondence: Alba García-Fernández; Ramón Martínez-Máñez Email algarfe4@etsia.upv.es; rmaez@qim.upv.es
Introduction: Breast cancer has the highest mortality rate among cancers in women. Patients suffering from certain breast cancers, such as triple-negative breast cancer (TNBC), lack effective treatments. This represents a clinical concern due to the associated poor prognosis and high mortality. As an approach to succeed over conventional therapy limitations, we present herein the design and evaluation of a novel nanodevice based on enzyme-functionalized gold nanoparticles to efficiently perform enzyme prodrug therapy (EPT) in breast cancer cells.

Results: In particular, the enzyme horseradish peroxidase (HRP) - which oxidizes the prodrug indole-3-acetic acid (IAA) to release toxic oxidative species - is incorporated on gold nanoconjugates (HRP-AuNCs), obtaining an efficient nanoplatform for EPT. The nanodevice is biocompatible and effectively internalized by breast cancer cell lines. Remarkably, co-treatment with HRP-AuNCs and IAA (HRP-AuNCs/IAA) reduces the viability of breast cancer cells below 5\%. Interestingly, 3D tumor models (multicellular tumor spheroid-like cultures) co-treated with HRP-AuNCs/IAA exhibit a 74\% reduction of cell viability, whereas the free formulated components (HRP, IAA) have no effect.

Conclusion: Altogether, our results demonstrate that the designed HRP-AuNCs nanoformulation shows a remarkable therapeutic performance. These findings might help to bypass the clinical limitations of current tumor enzyme therapies and advance towards the use of nanoformulations for EPT in breast cancer.

Keywords: gold nanoconjugates, horseradish peroxidase, indole-3-acetic acid, enzyme prodrug therapy, breast cancer

\section{Introduction}

Breast cancer is the most commonly diagnosed cancer and the leading cause of death among women worldwide, accounting for $24 \%$ of total cancer cases with $15 \%$ of related mortality. ${ }^{1,2}$ Currently, main treatment strategies are surgery, radiotherapy, chemotherapy, and hormone therapy. ${ }^{3}$ A significant shortcoming associated with those therapies is the lack of specificity, which leads to reduced efficacy and dose-limiting side effects (i.e., nausea, fatigue, infertility, cardiac dysfunction, etc.). ${ }^{4}$ In this scenario, nanoparticle-based therapies for controlled release and tumor-targeted delivery of these drugs represent an essential technology to improve treatment outcomes. The use of nanoparticles provides many potential benefits; including increased drug solubility, decrease degradation during circulation, and targeting to the desired locations. Moreover, nanocarriers present the advantage of 
accumulating preferentially in solid tumors, through the EPR effect. ${ }^{5,6}$ This unique phenomenon is considered the landmark of nanoparticle passive targeting, which is translated into the therapeutic improvement derived from treatment with nanomaterials. ${ }^{7}$ Overall, the ability of nanotechnology to improve the pharmacologic profile of a drug promises to increase efficacy while decreasing unwanted side effects. ${ }^{8}$

On the other hand, enzymes have been investigated as effective agents for cancer treatment. ${ }^{9,10}$ Particularly, enzyme prodrug therapy (EPT) emerged as a novel therapeutic approach, where enzymes catalyze the activation of prodrugs to produce toxic drugs at targeted locations. ${ }^{11}$ The principle of EPT for oncological treatment relies on the specific prodrug activation in the tumor site for the efficient elimination of cancer cells, while sparing healthy tissues. ${ }^{12}$ However, poor enzyme/prodrug stability, potential immunogenicity and limited delivery to target areas are critical limiting factors hampering EPT. ${ }^{13,14}$ Consequently, advances in the development of efficient delivery systems that circumvent these issues could be of importance. Within this context, directed enzyme prodrug therapy (DEPT) has been proposed, which mainly relies on the use of antibodies ${ }^{14,15}$ and viruses ${ }^{16,17}$ as enzyme vehicles. However, these approaches are still limited - their clinical application is mainly hindered by the potential immunogenicity and the risk of mutation of the viral vectors. ${ }^{14,18}$

Another possible approach to overcome the limitations of conventional DEPT is to use abiotic nanoparticles as delivery systems. Several studies have focused on conjugating therapeutic enzymes on different nanomaterials, such as liposomes, ${ }^{19,20}$ polymers, ${ }^{21,22}$ iron oxide nanoparticles, ${ }^{23,24}$ and silica nanoparticles. ${ }^{25,26}$ Among inorganic nanomaterials, gold nanoparticles (AuNPs) present unique chemical, physical and biological properties that make them ideal scaffolds to be exploited for biomedical applications. Their biocompatibility has been demonstrated in vitro ${ }^{27,28}$ and in vivo. ${ }^{29,30}$ Moreover, their synthesis is straightforward with tunable size $(1-200 \mathrm{~nm})^{31-33}$ and shape (ie, spherical, rods, star nanoparticles, etc.). ${ }^{34}$ Further versatility is given by ready surface functionalization with biomolecules, such as enzymes, ${ }^{35,36}$ oligonucleotides, ${ }^{37,38}$ proteins, ${ }^{39,40}$ drugs, ${ }^{41-43}$ and its potential incorporation in Janus-like ensembles for advanced applications. ${ }^{44-47}$ In turn, gold nanoparticles hold special interest as enzyme nanocarriers. Enzyme conjugation with AuNPs has demonstrated to increase the enzyme stability, ${ }^{48,49}$ as well as the enzyme affinity for the substrate. ${ }^{50,51}$ As a consequence, enzyme nanoformulation in gold nanoparticles is presented as a plausible solution for the handicap of poor stability associated with enzyme therapy, which could improve enzyme effectivity and therapeutic effect in the tumor. However, despite their numerous advantages, the utility of AuNPs for EPT applications in cancer treatment has still not been explored as far as we know.

In this work, we present the design and evaluation of enzyme-functionalized AuNPs conjugates (AuNCs) as a novel nano-bio-platform to perform EPT in breast cancer tumor cells. We chose the enzyme-prodrug system consisting of the enzyme horseradish peroxidase (HRP) and the prodrug indole-3-acetic acid (IAA). Horseradish peroxidase (HRP; EC 1.11.1.7) is a redox glycoenzyme with an accessible ferroprotoporphyrin group at the active site, which is naturally found in horseradish roots. ${ }^{52}$ From a biomedical point of view, HRP presents numerous advantageous features, namely, biocompatibility, high stability at $37^{\circ} \mathrm{C}$, high catalytic activity at neutral $\mathrm{pH}$, and the possibility of conjugation to nanoparticles and antibodies. ${ }^{53}$ In recent years, HRP has gained remarkable attention in cancer research, since in combination with IAA, has demonstrated antitumor activity in vitro ${ }^{54,55}$ and in vivo. ${ }^{56,57}$ On the other hand, indole-3-acetic acid is a naturally occurring plant growth phytohormone ${ }^{58}$ that can be used as a non-toxic prodrug as it is well-tolerated by humans. ${ }^{59,60}$ Horseradish peroxidase catalyzes the oxidation of IAA to release free radicals (ie: indolyl, skatolyl, peroxyl radicals) and reactive oxygen species (ROS) (ie, $\mathrm{O}^{-}{ }_{2}^{-}$, and $\mathrm{H}_{2} \mathrm{O}_{2}$ ), which induce oxidative stress and cell death by activating apoptotic pathways. ${ }^{61,62}$ Based on the above, we report herein the preparation of AuNPs decorated with HRP (HRP-AuNCs) and its biological evaluation for EPT applications in combination with the prodrug indole-3-acetic acid (IAA). Our results demonstrate that HRP-AuNCs is biocompatible and shows remarkable antitumoral activity in breast cancer cell cultures and in 3D tumor spheroid models. As far as we know, our report herein describes the first use of AuNCs as an enzyme carrier system for breast cancer EPT.

\section{Materials and Methods}

\section{Synthesis of Gold Nanoparticles (AuNPs)}

Gold nanoparticles were synthesized based on the Turkevich-Frens method. ${ }^{63,64}$ Briefly, $100 \mathrm{~mL}$ of $0.34 \mathrm{mM}$ $\mathrm{HAuCl}_{4} \cdot 3 \mathrm{H}_{2} \mathrm{O}$ solution was brought to $100{ }^{\circ} \mathrm{C}$ under stirring and refluxing. Then, $1.5 \mathrm{~mL}$ of a $1 \%$ sodium citrate solution was added to synthesize $20 \mathrm{~nm}$ gold 
nanoparticles. The initially faint yellow color turns to blue-black and finally red wine in $10 \mathrm{~min}$. After this, the colloidal suspension was let cool at room temperature.

\section{Synthesis of HRP-Functionalized Gold Nanoconjugates (HRP- AuNCs)}

Twenty milliliters of the $20 \mathrm{~nm}$ colloidal suspension of AuNPs were mixed with $20 \mu \mathrm{L}$ of 3-mercaptopropionic acid (3-MPA) and stirred for $1 \mathrm{~h}$. The red wine solution turns to a blue-black color due to the formation of nanoconjugates. After $1 \mathrm{~h}$, the solid (3-MPA)-AuNPs were isolated by centrifugation at $9500 \mathrm{rpm}$ for $20 \mathrm{~min}$. Then, the nanoparticles were washed with ethanol by centrifugation-washing cycles of $5 \mathrm{~min}$ at 12,500 rpm. In the next step, the (3-MPA)-AuNPs were reacted with $1 \mathrm{mg}$ of $\mathrm{N}$-(3-dimethylaminopropyl)- $\mathrm{N}^{\mathrm{I}}$-ethylcarbodiimide (EDC) and $1 \mathrm{mg}$ of $\mathrm{N}$ - hydroxysuccinimide (NHS) under stirring for $30 \mathrm{~min}$. Finally, $2 \mathrm{mg}$ of HRP (type VI) were added to the mixture and stirred overnight at $4{ }^{\circ} \mathrm{C}$. The final HRPAuNCs were isolated by centrifugation-washing cycles of $5 \mathrm{~min}$ at 12,500 rpm in PBS buffer.

\section{Standard Characterization Procedures of HRP-AuNCs}

Transmission electron microscopy coupled with energydispersive X-ray spectroscopy (TEM-EDX) and ultraviolet-visible (UV-Vis) spectrophotometry, dynamic light scattering (DLS), and $\zeta$ potential were employed for the nanomaterial characterization. TEM-EDX imaging was carried out using a JEM-2100 LaB6 electron microscope (from JEOL Ldt. Japan), working at $200 \mathrm{kV}$ accelerating voltage and equipped with an Oxford Instruments INCA $\mathrm{x}$-sight ( $\mathrm{Si}(\mathrm{Li})$ detector) and a Zeiss SESAM microscope $(200 \mathrm{kV})$ equipped with an energy dispersive X-ray (EDX) spectroscopy system (from ThermoFisher, USA) UVvisible spectra were recorded with a V-650 UV-VIS Spectrophotometer (from JASCO, Germany). The DLS studies determined particle size were conducted at $25{ }^{\circ} \mathrm{C}$ in a Zetasizer Nano ZS instrument (Malvern Panalytica, UK). The $\zeta$ potential was calculated from the particle mobility values by applying the Smoluchowski model. All the measurements were taken in triplicate. FTIR measurements were performed using a Tensor 27 Spectrometer (from Bruker, USA). The total amount of HRP attached to the AuNCs was determined following the Pierce BCA Protein Assay Kit.

\section{HRP Activity Assay}

The method we used to determine HRP activity was based on the enzymatic oxidation of 2,2'-Azino-bis(3-ethylbenzothiazoline-6-sulfonic acid) diammonium salt (ABTS) according to Sigma Aldrich instructions. ${ }^{65,66}$ HRP catalyzes a redox reaction with ABTS and $\mathrm{H}_{2} \mathrm{O}_{2}$ as substrates. The ABTS is oxidized to produce the ABTS cation radical, which can be measured as a color change at $405 \mathrm{~nm}$. The $\mathrm{H}_{2} \mathrm{O}_{2}$ is reduced to yield $\mathrm{H}_{2} \mathrm{O}$.

\section{$\mathrm{H}_{2} \mathrm{O}_{2}+\mathrm{ABTS} \rightarrow 2 \mathrm{H}_{2} \mathrm{O}+$ oxidized ABTS}

In order to measure the activity of the free HRP and HRP-AuNCs a reaction mixture was prepared as follows: $966.7 \mu \mathrm{L}$ of $9.1 \mathrm{mM}$ of ABTS (8.7 mM), $33.3 \mu \mathrm{L}$ of $0.3 \%$ (w/w) of $\mathrm{H}_{2} \mathrm{O}_{2}(0.01 \% \mathrm{w} / \mathrm{w})$, and $10 \mu \mathrm{L}$ of $1 \mathrm{mg} / \mathrm{mL}$ of HRPAuNCs $(0.01 \mathrm{mg} / \mathrm{mL})$ or $16.6 \mu \mathrm{L}$ of $1 \times 10^{-8} \mathrm{mg} / \mathrm{mL}$ free HRP $\left(1.66 \times 10^{-10} \mathrm{mg} / \mathrm{mL}\right)$. The peroxidase-like activity of the starting AuNPs was also evaluated at the same conditions of HPR-AuNCs. The absorbance was monitored at $405 \mathrm{~nm}$ as a function of time for $2 \mathrm{~min}$. The ABTS solution was prepared in $100 \mathrm{mM}$ phosphate buffer $(\mathrm{pH} \mathrm{5)}$ and the free HRP was dissolved in 40mM phosphate buffer ( $\mathrm{pH} 6.8$ ).

Peroxidase activity of free HRP was estimated by applying the equation:

$$
\frac{\text { Enzyme units }}{\mathrm{mg}}=\frac{\left(\Delta-\Delta_{\text {Blank }}\right) \times \mathrm{V}_{\mathrm{T}} \times \mathrm{F}_{\mathrm{D}}}{\varepsilon_{\mathrm{ABTS}} \times \mathrm{L} \times \mathrm{V}_{\mathrm{HRP}}}
$$

The peroxidase activity of HRP-AuNCs and AuNPs required slightly variations in the equation:

$$
\frac{\text { Enzyme units }}{\mathrm{mg}}=\frac{\left(\Delta-\Delta_{\text {Blank }}\right) \times \mathrm{V}_{\mathrm{T}}}{\varepsilon_{\mathrm{ABTS}} \times \mathrm{L} \times \mathrm{V}_{\mathrm{HRP}-\mathrm{AuNCs}}}
$$

Where, $\Delta$ is the slope of the graph $\left(\min ^{-1}\right), \Delta_{\text {Blank }}$ is the slope of the graph for the blank $\left(\mathrm{min}^{-1}\right), \mathrm{V}_{\mathrm{T}}$ is the total volume in the cuvette, $F_{D}$ is the dilution factor of enzyme, $\varepsilon_{\mathrm{ABTS}}$ is the molar extinction of oxidized ABTS ${ }^{-}$at 405 $\mathrm{nm}\left(36.8 \mathrm{mM}^{-1} \mathrm{~cm}^{-1}\right), \mathrm{L}$ is the optical path in the cuvette $(1 \mathrm{~cm}), \mathrm{V}_{\mathrm{HRP}}$ is the volume of enzyme added $(\mathrm{mL})$ and $\mathrm{V}_{\text {HRP-AuNCs }}$ is the volume of nanoconjugates added $(\mathrm{mL})$.

\section{Cell Culture Conditions}

Triple-negative breast cancer cells (MDA-MB-231) and Hormone receptor-positive MCF-7 cells were purchased from ATCC. Cells were grown in Dulbecco's Modified Eagle Medium (DMEM)-high glucose supplemented with $10 \%$ fetal bovine serum (FBS) and incubated at $37{ }^{\circ} \mathrm{C}$ in a $5 \% \mathrm{CO}_{2}$ atmosphere and $95 \%$ air. Cells were periodically detached with trypsin-EDTA $(0.25 \% \mathrm{w} / \mathrm{w})$, diluted, and incubated with fresh culture media. 


\section{Biocompatibility Studies with HRP-AuNCs}

The biocompatibility of HRP-AuNCs was assessed in MDA-MB-231 and MCF-7. The cytotoxic effect was evaluated by WST-1 assay. MDA-MB-231 (10,000 cells/well) and MCF-7 (7500 cells/well) were seeded on 96-well plates overnight. The cells were treated with HRPAuNCs at different concentrations $(0,100,200,500$, and $750 \mu \mathrm{g} / \mathrm{mL}$ ) for $48 \mathrm{~h}$. After that incubation time, WST-1 (10 $\mu \mathrm{L} /$ well) was added and incubated for $1 \mathrm{~h}$. The absorbance was recorded at $450 \mathrm{~nm}$ at Wallace 1420 workstation (from PerkinElmer, USA).

\section{Cellular Uptake Studies}

The cellular internalisation of HRP-AuNCs was studied in MDA-MB-231 and MCF-7 by TEM. MDA-MB-231 (50,000 cells/well) and MCF-7 (35,000 cells/well) were seeded on 8-well chamber slide (ThermoFisher Scientific 177445) the day before treatment. The cells were treated with HRP-AuNCs at $50 \mu \mathrm{g} / \mathrm{mL}$. After $6 \mathrm{~h}$ of incubation with the nanoconjugates, the cells were carefully washed with PBS and incubated with 3\% glutaraldehyde prepared in PBS at $37^{\circ} \mathrm{C}$ for $10 \mathrm{~min}$. Then, the glutaraldehyde was replaced with fresh $3 \%$ glutaraldehyde, and cells were incubated for $2 \mathrm{~h}$ at room temperature. Finally, the cells were washed 5 times with PBS and keep at $4{ }^{\circ} \mathrm{C}$ for further TEM visualization. The fixed cell samples were further processed in the TEM service of the Centro de Investigación Principe Felipe and finally, the images were acquired using a microscope FEI Tecnai Spirit G2 operating at $80 \mathrm{kV}$ with a digital camera (Soft Image System, Morada).

\section{HRP-AuNCs for EPT in Breast Cancer Cells}

Enzyme prodrug therapy carried out by the starting AuNPs, HRP-AuNCs, and free HRP was evaluated in MDA-MB-231 (10,000 cells/well) and MCF-7 (7500 cells/well) cell lines. The cells were seeded on 96-well plates one day before treatment. The cytotoxic effect of EPT was assessed after treatment with AuNPs, HRPAuNCs, or free HRP in the absence or presence of IAA at a concentration of $500 \mu \mathrm{M}$ for $48 \mathrm{~h}$. AuNPs were used at different concentrations (200, 300 and $400 \mu \mathrm{g} / \mathrm{mL}$ ). HRP-AuNCs were used at the enzyme activity of $7.85 \times$ $10^{-2} \mathrm{U} / \mathrm{mL}$ (equivalent to $0.85 \mu \mathrm{g}$ of HRP). Free HRP were used at the enzyme activity found in the nanoparticles (Free HRP EqAct) at $7.85 \times 10^{-2} \mathrm{U} / \mathrm{mL}$ (equivalent to $2.88 \times 10^{-7} \mu \mathrm{g}$ of HRP) in combination with IAA to compare the efficacy of our system. Besides, free HRP at the standard dose reported in the bibliography (Free HRP) corresponding to $1.2 \mu \mathrm{g} / \mathrm{mL}$ (equivalent to $3.24 \times 10^{4} \mathrm{U} / \mathrm{mL}$ ) in combination with IAA was also used as positive control to ensure the cytotoxic effect derived from the HRP-AuNCs/IAA system. Untreated cells and single-agent treatment, ie, AuNPs, HRPAuNCs, Free HRP EqAct, free HRP, or IAA alone, were used as controls. After $48 \mathrm{~h}$ of incubation, WST-1 (10 $\mu \mathrm{L} /$ well) was added and incubated for $1 \mathrm{~h}$. The absorbance was recorded at $450 \mathrm{~nm}$ at Wallace 1420 workstation.

\section{Reactive Oxygen Species Measurement}

To confirm the oxidative stress induced by the HRPAuNCs and IAA treatment was measured using the CMH2DCFDA stain (Ref C6827 from ThermoFisher) as a general ROS indicator. For this purpose, EPT therapy was mimicked by incubating HRP-AuNPs or free HRP in the absence or presence of IAA on a 96-well plate as described above. Free HRP was used in equivalent activity to HRP attached to the nanoparticles (Free HRP EqAct at $7.85 \times 10^{-2} \mathrm{U} / \mathrm{mL}$, equivalent to $2.88 \times 10^{-7} \mu \mathrm{g}$ of HRP) or at $1.2 \mu \mathrm{g} / \mathrm{mL}\left(3.24 \times 10^{4} \mathrm{U} / \mathrm{mL}\right)$, as the established dose in previous reports (positive control) in combination with IAA to compare the ROS generation. Besides, $\mathrm{H}_{2} \mathrm{O}_{2}$ was used as a positive control of the fluorescence probe. Then, CM-H2DCF was added at $5 \mu \mathrm{M}$ and fluorescent was monitored for $2 \mathrm{~h}$ on Wallace 1420 workstation.

\section{HRP-AuNCs for EPT in Triple-Negative Breast Cancer 3D Tumor Spheroid Models}

Multicellular tumors spheroids-like cultures were prepared according to the literature with slight modifications. ${ }^{67,68}$ Briefly, $1.5 \%$ of agarose was added to PBS and autoclaved. Next, $50 \mu \mathrm{L} /$ well of hot $\left(80-90{ }^{\circ} \mathrm{C}\right)$ solution were added to a 96-well plate (flat bottom) under sterile conditions. After agarose solidification, a concave non-adherent bottom was obtained. The MDA-MB-231 cells grown as a monolayer were detached with trypsin to generate a single-cell suspension. Then, cells were seeded at 5000 cells/well in a final volume of $200 \mu \mathrm{L} /$ well and centrifuged at $1000 \mathrm{rpm}$ for 10 min. Matrigel thawed at $4{ }^{\circ} \mathrm{C}$ overnight was added a final concentration of $2.5 \%$ with ice-cold pipette tips to each well. The plates were incubated under standard cell culture 
conditions $\left(37^{\circ} \mathrm{C}, 5 \% \mathrm{CO}_{2}\right.$, in a humidified incubator) for 3 days. Afterward, the spheroid-like culture was treated with the HRP-AuNCs at $0.15 \mathrm{U} / \mathrm{mL}$ (equivalent to $1.62 \mu \mathrm{g}$ of HRP) in the absence or presence of IAA at a concentration of $250 \mu \mathrm{M}$. Free HRP were used at the enzyme activity found in the nanoparticles (Free HRP EqAct) at $0.15 \mathrm{U} / \mathrm{mL}$ (equivalent to $5.55 \times 10^{-7} \mu \mathrm{g}$ of HRP), and at the standard dose reported in the bibliography (Free HRP) corresponding to $1.2 \mu \mathrm{g} / \mathrm{mL}$ (equivalent to $3.24 \times 10^{4} \mathrm{U} / \mathrm{mL}$ ). Untreated and single-agent treated cells (ie, HRP-AuNCs, Free HRP EqAct, free HRP, or IAA alone) were employed as controls. After $48 \mathrm{~h}$ of incubation, the cell viability was determined by WST-1 assay. WST-1 reagent ( $20 \mu \mathrm{L} /$ well) was added to each well and incubated for $4 \mathrm{~h}$. Finally, the absorbance was measured at 450 in a Wallace 1420 workstation.

\section{Results and Discussion \\ Synthesis and Characterization of HRP-AuNCs}

To prepare the nanodevice, we first synthetized AuNPs by reduction of $\mathrm{Au}^{\text {III }}$ with sodium citrate, according to the Turkevich-Frens method. ${ }^{63,64}$ The resulting AuNPs were functionalized with 3-mercaptopropionic acid (3-MPA) to obtain the nanoconjugates termed as (3-MPA)-AuNCs. The carboxylic group of (3-MPA)-AuNCs was activated by EDC/ NHS reaction and then reacted with amino groups of the HRP enzyme. This resulted in the final gold nanoconjugate decorated with covalently attached HRP through amide bonds (HRP-AuNCs) (Figure 1A and Figure S1). The prepared nanoparticles were expected to be internalized by breast cancer cells and produce free radical species upon treatment with the prodrug IAA. Free radicals are known to induce apoptotic cell death by regulating intracellular signal transduction pathways (Figure 1B). ${ }^{69,70}$

The prepared nanodevices were characterized using TEM imaging, TEM coupled with energy-dispersive X-ray spectroscopy (TEM-EDX), ultraviolet-visible (UVVis) spectrophotometry, FTIR spectrometry, dynamic light scattering (DLS) and $\zeta$ potential. TEM images of HRPAuNCs at low magnification showed multiple spherical gold nanoparticles with an average size of $19 \pm 4 \mathrm{~nm}$ $(\mathrm{N}=134)$ (Figure $\mathrm{S} 2$ ). Moreover, TEM-EDX mapping (Figure 2A) showed the presence of $\mathrm{Au}$ atoms from the gold scaffold, $\mathrm{S}$ atoms from 3-MPA, and $\mathrm{N}$ atoms from the enzyme. Furthermore, UV-Vis measurements (Figure 2B) of the starting AuNPs showed a single absorption band at
$524 \mathrm{~nm}$, characteristic of the surface plasmon resonance of spherically shaped nanospheres with an approximately 20 $\mathrm{nm}$ diameter. In the HRP-AuNCs, the $524 \mathrm{~nm}$ band was broadened and displaced to longer wavelengths which suggested the formation of nanoconjugates via aggregation of single nanoparticles. The FT-IR spectrum showed the absorption bands associated with the different functionalization processes carried out in the synthesis of the final nanodevices (Figure S3). The presence of the citrate carboxyl groups that stabilize the colloidal AuNPs was observed at $1690 \mathrm{~cm}^{-1}$. Moreover, the functionalization with the 3-MPA ligand was confirmed by the appearance of distinct peaks at 2914 and $2845 \mathrm{~cm}^{-1}$ related to the vibrations of the $-\mathrm{CH}_{2}$ groups, while the characteristic band of the terminal carboxyl groups appeared at $1700 \mathrm{~cm}^{-1}$. Finally, the HRP immobilization on the AuNCs surface was also demonstrated by the characteristic amide absorption bands of proteins, assigned to the vibrational stretches of $\mathrm{C}=\mathrm{O}$ and $\mathrm{CN}$ bonds and the bending of $\mathrm{NH}$ bond at 1650,1058 and $1550 \mathrm{~cm}^{-1}$, respectively. In addition, the hydroxyl groups of the enzyme were also observed at $3290 \mathrm{~cm}^{-1}$. We also monitored the preparation process of the final nanodevices measuring the DLS and the $\zeta$ potential. The hydrodynamic diameter increased after each preparation step (Figure 2B). The starting gold colloid showed a hydrodynamic diameter of $25.7 \pm 0.2 \mathrm{~nm}$. The functionalization of the AuNPs with 3-MPA to obtain (3-MPA)-AuNCs increased the hydrodynamic size to $222 \pm 17 \mathrm{~nm}$, which indicated the formation of the nanoconjugates of AuNPs. The subsequent HRP attachment yielded the HRP-AuNCs with a hydrodynamic diameter of $376 \pm 29 \mathrm{~nm}$. In relation to $\zeta$ potential (Figure 2C), functionalization with 3-MPA increased the $\zeta$ potential to $-35 \pm 4 \mathrm{mV}$. Further functionalization with HRP resulted in a $\zeta$ potential of $-15 \pm 2$ $\mathrm{mV}$, which indicated the correct incorporation of the positively charged enzyme to the nanoconjugate's surface.

\section{Enzyme Activity and Stability of HRP-AuNCs}

Enzyme immobilization may result in alterations of the enzyme properties. ${ }^{71}$ Thus, it is critical to check the enzyme activity after enzyme conjugation with the nanoscaffold. This was carried out by measuring the specific peroxidase activity of HRP-AuNCs following a standard activity assay based on the ABTS oxidation (see materials and methods section). One unit (U) of HRP is defined as 
A

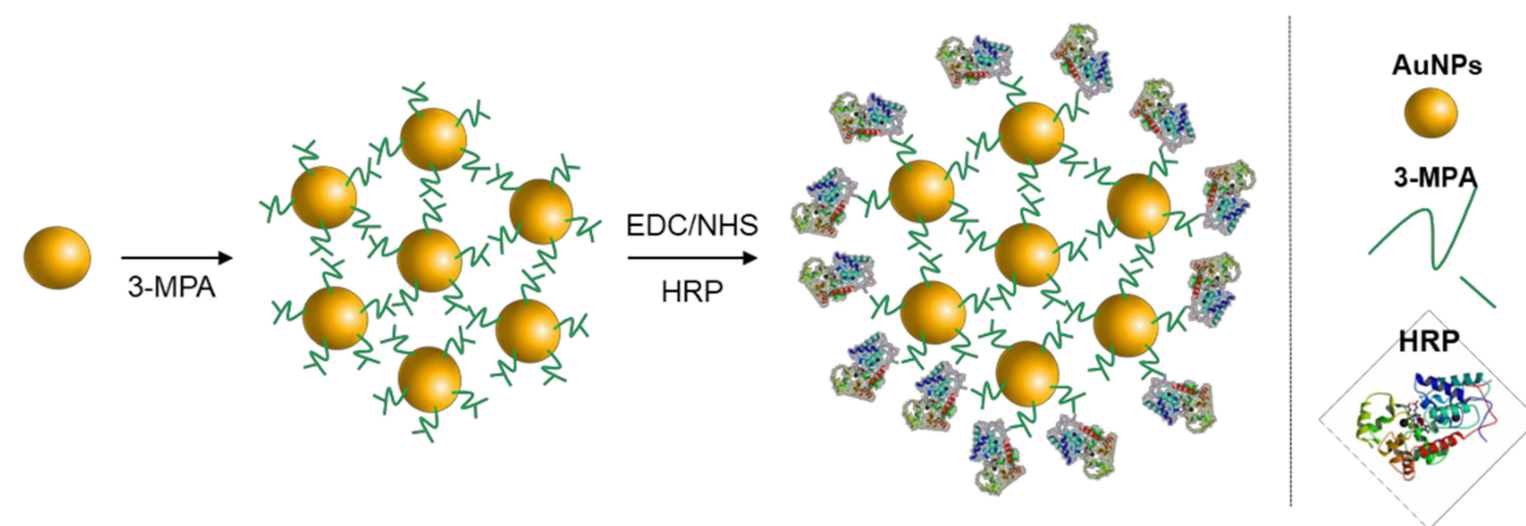

B

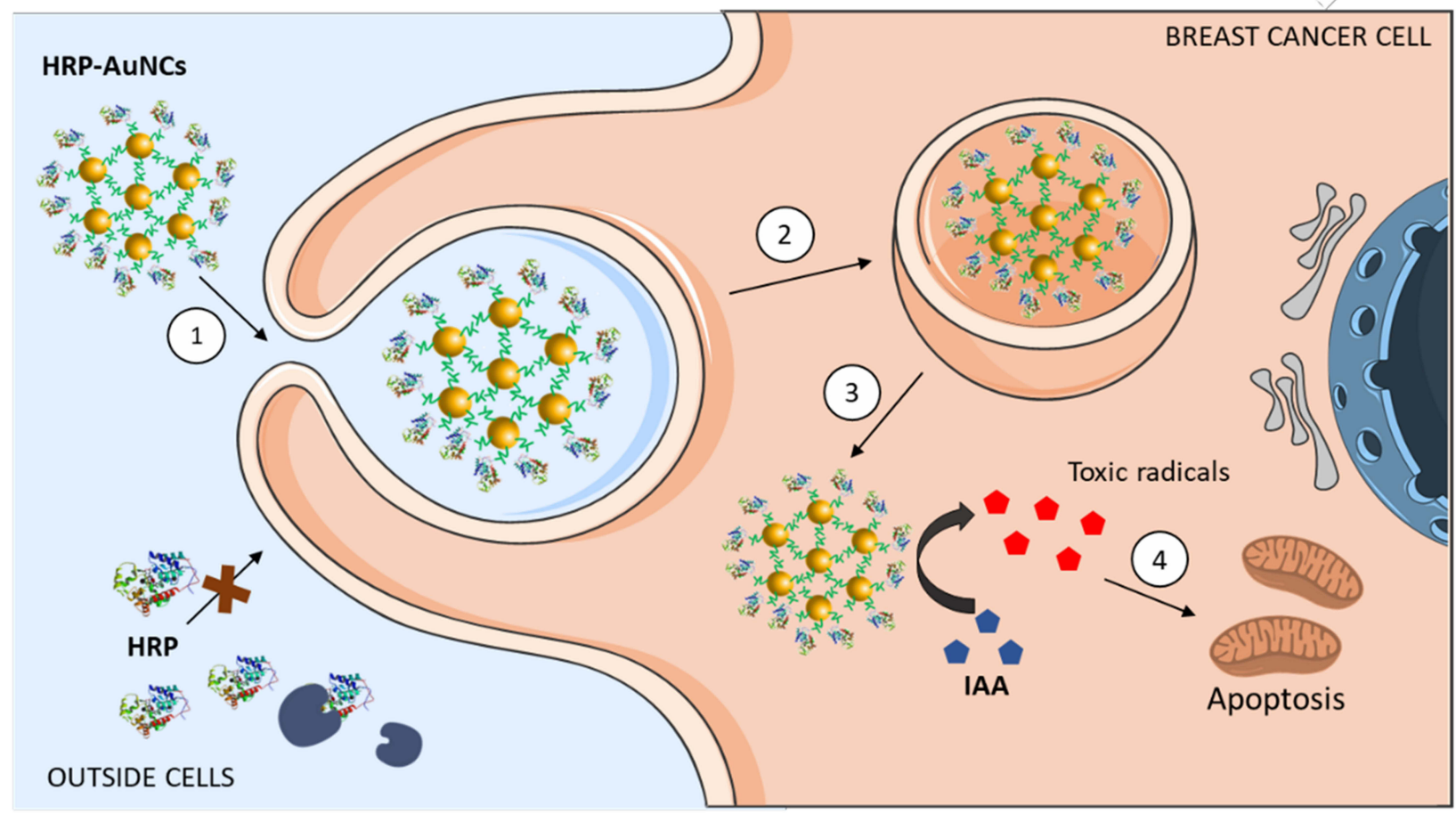

C

(3)
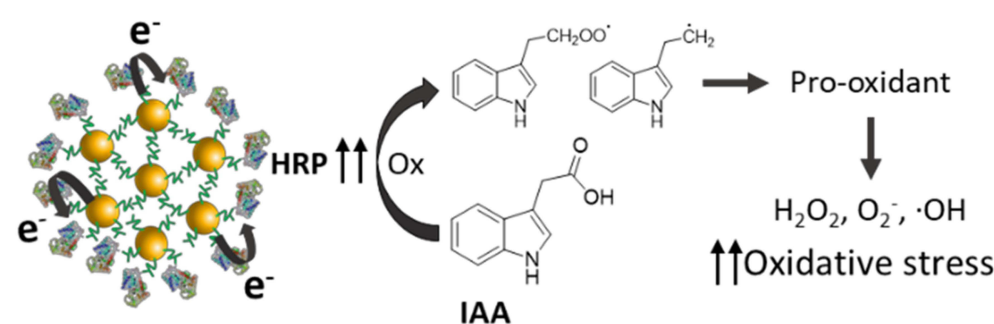

IAA

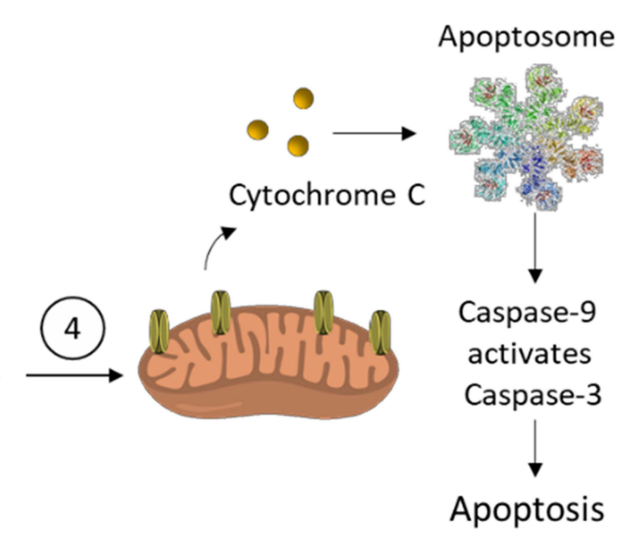

Figure I Representation of the design and synergistic therapeutic performance of HRP- AuNCs for EPT. A) Illustration of different steps for the assembly of HRP-AuNCs. Firstly, gold nanoparticles (AuNPs) are synthesised and functionalised with 3-MPA. Next, the carboxylic group in the gold nanoconjugates (3-MPA)-AuNCs was activated by EDC/NHS reaction. Afterwards, HRP was grafted through amide bond formation between the carboxylic group of the 3-MPA and the amine residues of the enzyme. B) Schematic representation of the enhanced therapeutic effect of HRP-AuNCs. HRP conjugated on the AuNCs leads to higher enzyme protection and internalization by endocytosis by cells $(1,2)$. Then, the HRP oxidises the exogenous prodrug IAAleading to the production of IAA-derived free radicals and ROS (3), which induce tumour cell death by apoptosis. C) Detailed illustration of the enhanced catalytic activity provided by the enzyme on the Au s urface ( 3 ) and which produces a significant transformation of IAA into toxic radicals (4). HRP-AuNCs transforms IAA into indolyl and peroxyl radicals that lead to ROS generation and subsequent cell death by activation of apoptosis. 
the amount of enzyme that oxidizes $1.0 \mu \mathrm{mol}$ of ABTS per minute at pH 5.0 at $25{ }^{\circ} \mathrm{C}$ [i.e., $\mathrm{H}_{2} \mathrm{O}_{2}+\mathrm{ABTS} \rightarrow 2 \mathrm{H}_{2}$ $\mathrm{O}+$ oxidized ABTS]. Based on this, the HRP activity on HRP-AuNCs was determined as $0.25 \mathrm{U}$ per $\mathrm{mg}$ of nanoparticles. Besides, we determined the total amount of HRP onto AuNCs by BCA assay, resulting in a value of $25 \mu \mathrm{g}$ of HRP per mg of nanoparticles. These results confirmed the proper conjugation of the enzyme to AuNCs while maintaining its activity.

Since the recent discovery that metal nanoparticles present intrinsic enzyme-mimetic activity similar to natural peroxidases, ${ }^{72}$ increasing attention has been paid to inorganic peroxidase mimetics. ${ }^{73,74}$ For this reason, we aimed to determine whether AuNPs presented intrinsic peroxidase activity by the ABTS oxidation assay. Nevertheless, negligible peroxidase mimetic activity was detected (Figure S4), which might be explained because of the lower affinity of AuNPs for $\mathrm{H}_{2} \mathrm{O}_{2}$ and ABTS compared to HRP. ${ }^{75}$ Consequently, we confirmed that the peroxidase activity of HRP-AuNCs can be attributed exclusively to the presence of the enzyme.

\section{Biocompatibility and Cellular Uptake of HRP-AuNCs}

Breast cancer is a complex disease, recognized as a set of diseases affecting the same anatomical structure but characterized by great heterogeneity within patients. Molecular expression of a variety of biomarkers led to breast cancer classification into subtypes. ${ }^{76}$ Among them, we explored the EPT efficacy in luminal A (the most common subtype of breast cancer) and TNBC (breast cancer subtype showing the poorest prognosis) cell lines (MCF-7 and MDA-MB-231 cells, respectively). In the first step, the biocompatibility of the nanodevice was tested. MDA-MB-231 and MCF-7 cell lines were incubated in presence of HRP-AuNCs at different concentrations $(0-750 \mu \mathrm{g} / \mathrm{mL})$. The results showed that HRP-AuNCs were well tolerated by both cell lines after 48 $\mathrm{h}$ of treatment (Figure 3A and B). Only the highest concentration of HRP-AuNCs showed certain toxicity in MDA-MB -231 cells. Therefore, the non-toxic range of 200-400 $\mu \mathrm{g} /$ $\mathrm{mL}$ of HPR-AuNCs was selected to perform further cell viability assays, for EPT therapy, corresponding to an equivalent amount of $0.85 \mu \mathrm{g}$ of HRP (enzymatic activity of $\left.7.85 \times 10^{-2} \mathrm{U} / \mathrm{mL}\right)$.
We also analyzed the internalization of the nanoconjugates as a critical previous step to conduct targeted EPT. To accomplish this aim, the breast cancer cell lines were incubated with HRP-AuNCs for $6 \mathrm{~h}$ before visualization by TEM. TEM images showed that HRP-AuNCs was successfully internalized by MDA-MB-231 (Figure 3C) and MCF-7 cells (Figure 3D). HRP-AuNCs were preferentially localized in endocytosis vesicles identified as secondary lysosomes. This data is consistent with previous studies, which indicated that gold nanoparticles are sequestered in lysosomes after following an endocytic pathway. ${ }^{77}$ In addition, previous reports employing protein-functionalized gold nanoconjugates found that they remain stable in biological media (DMEM and BSA) for at least 2 weeks. ${ }^{78,79}$ It has also been demonstrated that enzyme-immobilization onto nanoparticles prevents their denaturation and enhances long-term activity. ${ }^{80,81}$ In our case, the high nanoparticle internalization was expected to favor prodrug activation by HRP inside the tumor cells and thus enhancing the EPT therapeutic effect.

\section{HRP-AuNCs for EPT in Breast Cancer Cells}

As a next step, we set out to evaluate the utility of HRPAuNCs in combination with IAA (HRP-AuNCs/IAA) to induce breast tumor cell death through an oxidative stress mechanism. The efficiency of HRP-AuNCs/IAA for EPT was explored in both, luminal A and TNBC cell lines. MDAMB-231 and MCF-7 cells were treated with HRP-AuNCs at $7.85 \times 10^{-2} \mathrm{U} / \mathrm{mL}$ (equivalent to $0.85 \mu \mathrm{g}$ of HRP) in the absence or presence of IAA at $500 \mu \mathrm{M}$. After $48 \mathrm{~h}$ of incubation, cell viability was evaluated by WST-1 assay. A significant reduction in cell viability was observed in MDA-MB-231 (Figure 4A) and MCF-7 upon HRP-AuNCs /IAA treatment (Figure 4B), whereas no cell death was detected when cells were treated with HRP-AuNCs or IAA alone. We also evaluated the EPT efficiency using the free $\mathrm{HRP}$ at the equivalent enzyme activity (free HRP EqAct) to that found in the nanoparticles, being at $7.85 \times 10^{-2} \mathrm{U} / \mathrm{mL}$ (equivalent to $2.88 \times 10^{-7} \mu \mathrm{g}$ of HRP). Remarkably, free HRP EqAct/IAA treatment did not reduce the cell viability. Furthermore, free HRP at $1.2 \mu \mathrm{g} / \mathrm{mL}$ (free HRP) was used as a positive control of EPT according to the standard dose reported in the bibliography for cancer therapy, corresponding to $3.24 \times 10^{4} \mathrm{U} / \mathrm{mL}$. Although free HRP/IAA at this high 
A
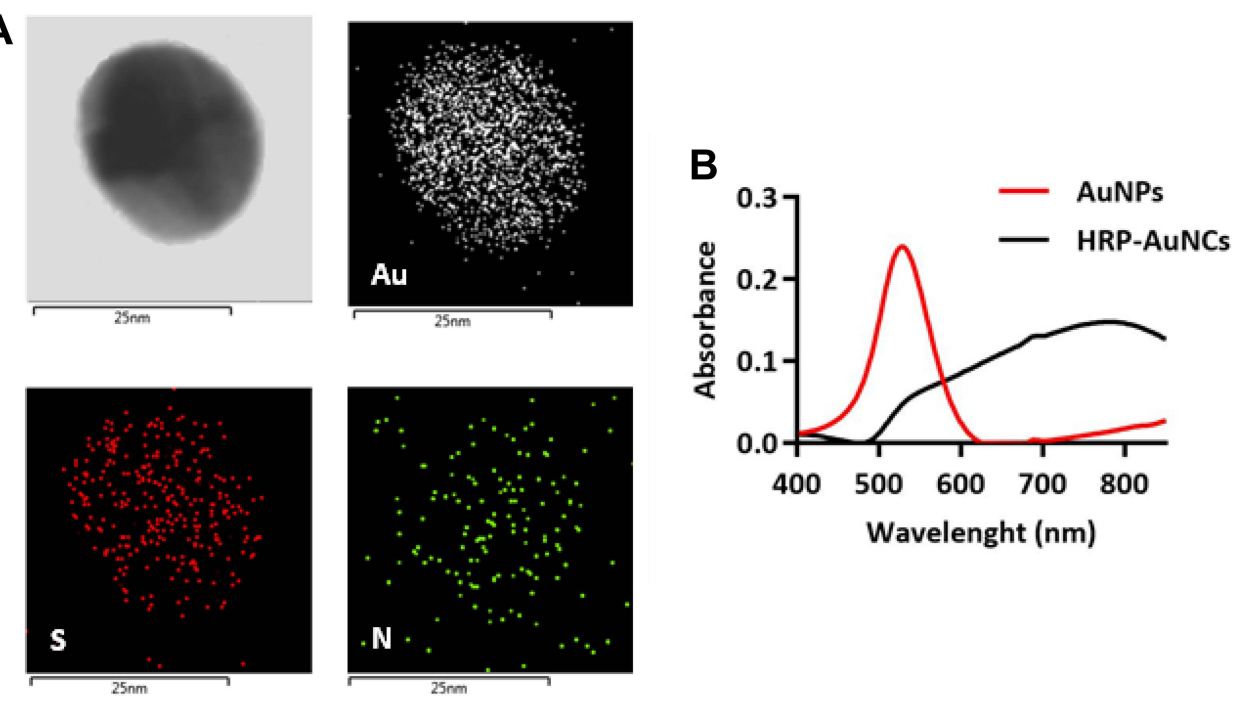

C

\begin{tabular}{ccc}
\hline Nanodevice & Hydrodynamic size $(\mathrm{nm}) \pm$ SD & Zeta potential $(\mathrm{mV}) \pm$ SD \\
\hline AuNPs & $25.7 \pm 0.2$ & $-37 \pm 3$ \\
(3-MPA)-AuNCs & $222 \pm 17$ & $-35 \pm 4$ \\
HRP-AuNCs & $376 \pm 29$ & $-15 \pm 2$
\end{tabular}

Figure 2 Characterisation of HRP-AuNCs. (A) TEM-EDX mapping of single HRP-AuNCs showing the presence of Au (from the gold scaffold), S (from the 3-MPA), and $\mathrm{N}$ (from the HRP). (B) UV-Vis spectra of AuNPs (red) and HRP-AuNCs (black). (C) Hydrodynamic size determined by dynamic light scattering and $\zeta$ potential of AuNPs, (3-MPA)-AuNCs and HRP-AuNCs. Data represent mean \pm SD $(n=3)$.

concentration significantly reduced cell viability, it did not reach the remarkable therapeutic effect achieved with HRPAuNCs.

Besides, we further evaluated the ability of AuNPs to perform EPT in combination with IAA (AuNPs/IAA) (Figure S5). As expected, and in concordance with ABTS oxidation assay (vide ante), neither AuNPs alone nor AuNPs/IAA treatments reduced the viability in the breast cancer cell lines.

On the other hand, considering the enhanced therapeutic effect observed by EPT mediated by HRP-AuNCs in breast cancer cells, the generation of ROS was determined for each treatment using a fluorescent oxidative stress indicator (CM-H2DCFDA) (Figure 4C). Fluorescence analysis confirmed the superiority of HRPAuNCs to catalyze the oxidation of IAA to release free radicals and ROS, compared to the free enzyme. Although HRP used at the standard reported dose (free HRP) exhibited a significant oxidative stress, when free
HRP was used at equivalent nanoconjugates' enzyme activity (free HRP EqAct), not significant effect was observed. This enhanced activity of the nanoconjugates could be potentially ascribed to the higher internalization of HRP when conjugated on AuNCs and to the previously described ability of AuNPs acting as electron acceptor or electron donor, which results in the restoring of the oxidized form of the reactive centre of reduced HRP and thus increasing their reactivity. ${ }^{51}$ Taken all the experiments together, on the one hand, ABTS oxidation assay demonstrated the peroxidase activity of the HRPAuNCs whereas negligible activity was observed for the bare AuNPs. On the other hand, cell experiments demonstrated that HRP-AuNCs showed higher performance (cell death, ROS production) than the free enzyme towards IAA. Thus, there is a synergistic effect from the HRP-AuNCs combination: conjugation on the nanoparticle leads to a higher enzyme internalization in cells and the catalytic activity provided by the enzyme 


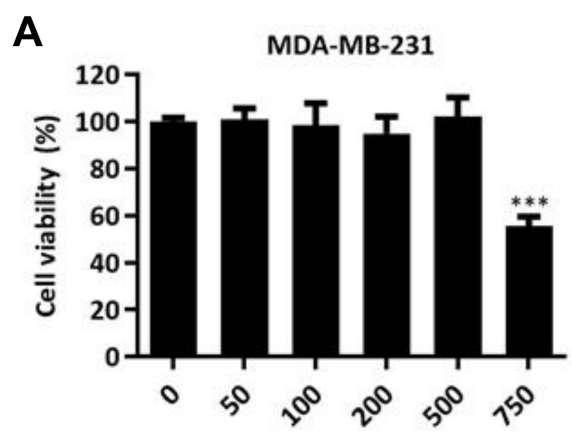

[HRP-AuNCs] $(\mu \mathrm{g} / \mathrm{mL})$
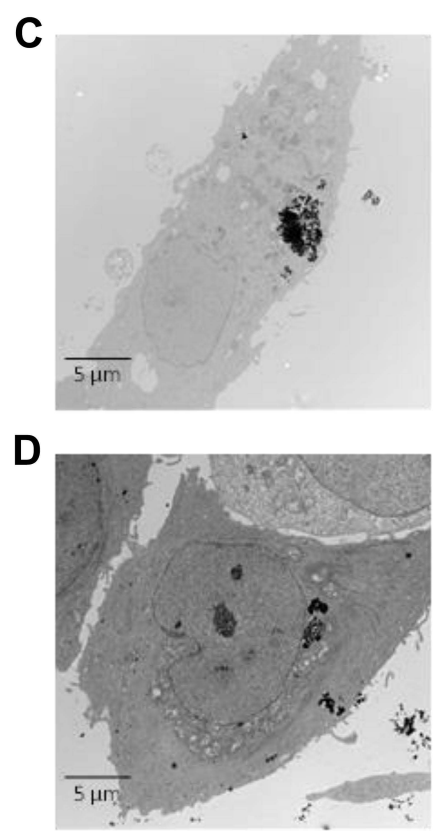

B
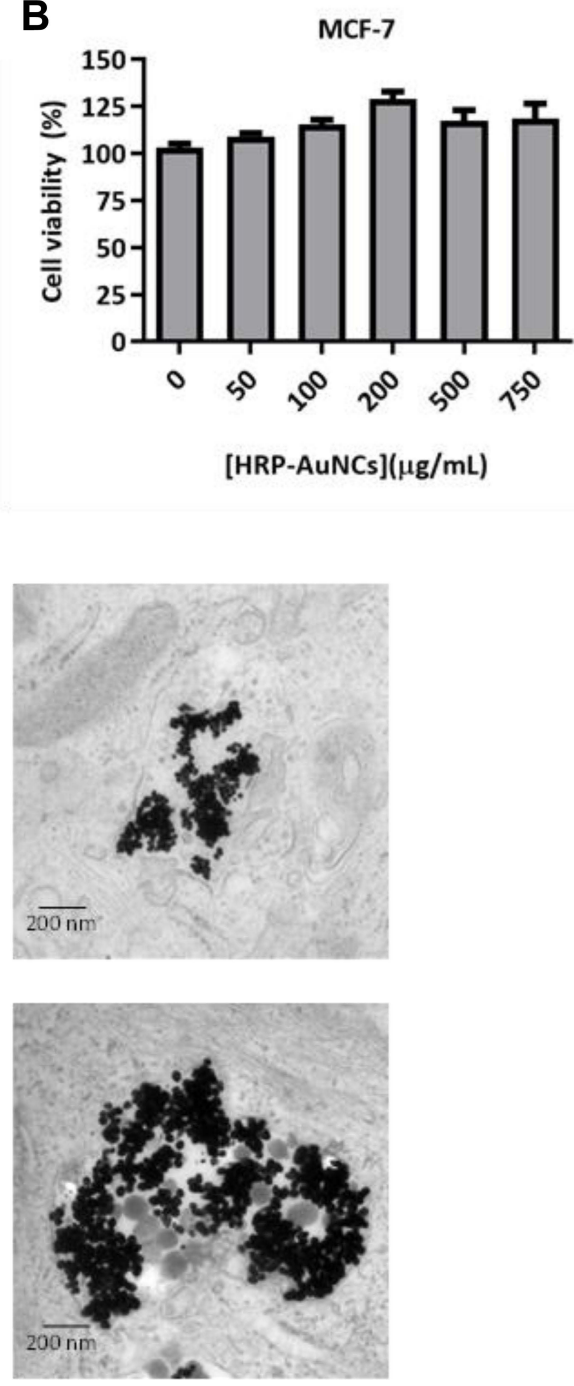

Figure 3 Biocompatibility and internalisation of HRP-AuNCs. Cytotoxicity profile of HRP-AuNCs in (A) MDA-MB-23I and (B) MCF-7 breast cancer cells. Cell viability was studied by WST-I assay in presence of different nanoparticle dosages after $48 \mathrm{~h}$ of incubation. Data represent means \pm SEM ( $\mathrm{n}=3$ ). Statistically significance was determined by one-way ANOVA and Dunnett post-test (*** $<0.00 \mathrm{I})$. TEM images demonstrating HRP-AuNCs uptake by (C) MDA-MB-23I and (D) MCF-7 after $6 \mathrm{~h}$ of incubation with $50 \mu \mathrm{g} / \mathrm{mL}$ of nanoconjugates.

on the Au surface produces a significant transformation of IAA. Then, as depicted in the schematic mechanism in Figure 1C, HRP-AuNCs transforms IAA into indolyl and peroxyl radicals that lead to ROS generation and subsequent cell death by activation of apoptosis. Considering the increased therapeutic effect and ROS production of HRP-AuNCs, HRP attachment onto gold nanoconjugates is presented as a crucial step to enhance therapeutic activity. HRP-AuNCs nanoformulation is a powerful strategy to increase the therapeutic applications of HRP/IAA systems.

\section{HRP-AuNCs for EPT in Breast Cancer 3D Tumor Spheroid Models}

Multicellular tumor spheroid cultures (MCTS) are 3D culture systems regarded as a more representative model on which to perform in vitro experiments. 3D cell cultures replicate in vivo-like behavior better than their twodimensional (2D) counterparts, due to recreating more of the characteristic traits of the native tumor microenvironment (such as cell-cell interactions, hypoxia, drug penetration, drug response, and resistance). ${ }^{82}$ Furthermore, MCTS represent a relevant physiological model as they 


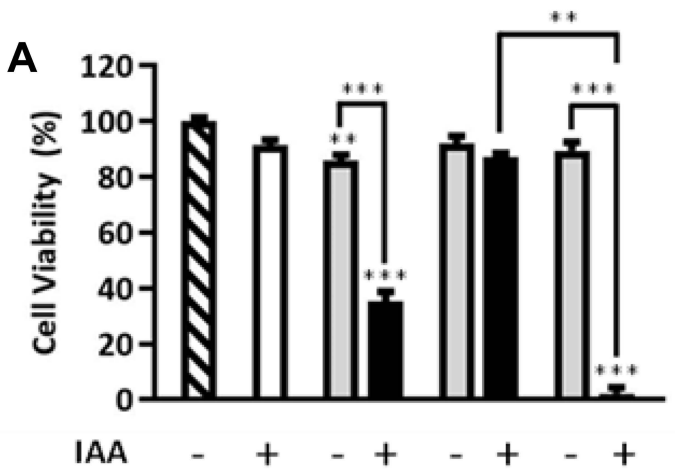

Free HRP

Free HRP EqAct

HRP-AuNCs

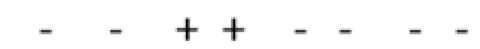

$++-$

$-\quad++$

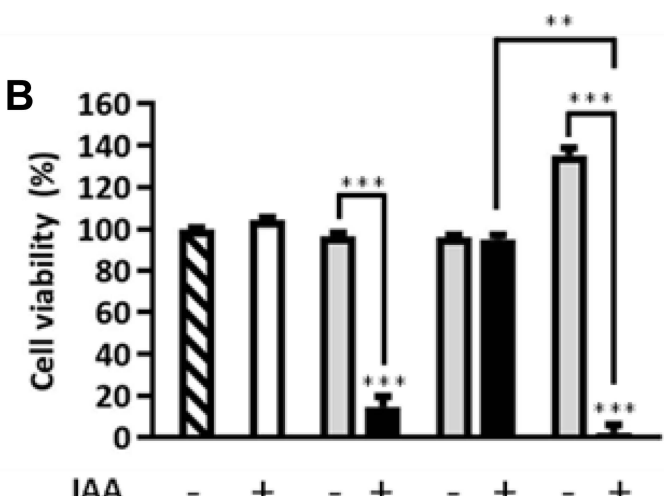

Free HRP

Free HRP EqAct

HRP-AUNCS

\section{C}

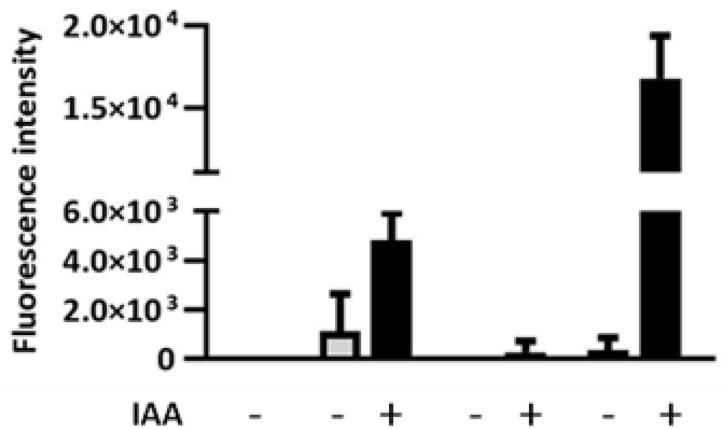

Free HRP

Free HRP EqAct

HRP-AuNCS

Figure 4 HRP-AuNCs for EPT in breast cancer cells. Cell viability assessment in (A) MDA-MB-23I and (B) MCF-7 treated with HRP-AuNCs at $7.85 \times 10^{-2} \mathrm{U} / \mathrm{mL}$ (equivalent to $0.85 \mu \mathrm{g}$ of HRP), free HRP EqAct at $7.85 \times 10^{-2} \mathrm{U} / \mathrm{mL}$ (equivalent to $2.88 \times 10^{-7} \mu \mathrm{g}$ of HRP) or free HRP at $1.2 \mu \mathrm{g} / \mathrm{mL}$ (equivalent to $3.24 \times 10^{4} \mathrm{U} / \mathrm{mL}$ of $\mathrm{HRP}$ ) in the absence or presence of IAA $(500 \mu M)$. Cell viability was determined after $48 \mathrm{~h}$ of incubation by WST-I assay. Data represent means \pm SEM $(n=3)$. Statistically significance was determined by one-way ANOVA; Dunns post-test for MDA-MB-23I and Tuckey post-test for MCF-7 ( $* * p<0.025, * * * p<0.00 \mathrm{I})$. (C) ROS induction with the different combinations of HRP-AuNCs $\left(7.85 \times 10^{-2} \mathrm{U} / \mathrm{mL}\right.$, equivalent to $0.85 \mu \mathrm{g}$ of HRP), free HRP EqAct $\left(7.85 \times 10^{-2} \mathrm{U} / \mathrm{mL}\right.$, equivalent to $2.88 \times 10^{-7} \mu \mathrm{g}$ of HRP) or free HRP (I.2 $\mu \mathrm{g} /$ $\mathrm{mL}$, equivalent to $3.24 \times 10^{4} \mathrm{U} / \mathrm{mL}$ of HRP) in the absence or presence of IAA (IAA $500 \mu \mathrm{M}$ ) using the CM-H2DCFDA probe as an oxidative stress indicator.

are enriched with cancer stem cells (CSC) or show stem cell-like features. Therefore, MCTS would predict in vivo tumor response more accurately than 2D cultures, and they constitute a more precise model in which to study tumor response to novel therapeutic agents.

Consequently, as a further step in the evaluation of the nanoconjugates, we studied the ability of HRP-AuNCs /IAA to induce cell death in multicellular tumor spheroidlike cultures. To carry out this study, we first created the
3D tumor spheroids from MDA-MB-231 cells using nonadhered culture plates (Figure S6). The spheroid-like cultures were incubated with HRP-AuNCs at $0.15 \mathrm{U} / \mathrm{mL}$ (equivalent to $1.62 \mu \mathrm{g}$ of HRP) in the absence or presence of IAA at a concentration of $250 \mu \mathrm{M}$ for $48 \mathrm{~h}$. While single treatments using HRP-AuNCs or IAA alone did not affect cell viability, the co-treatment using HRPAuNCs and IAA-induced spheroid cell death, by significantly reducing the cell viability down to $26 \%$ (Figure 5). 

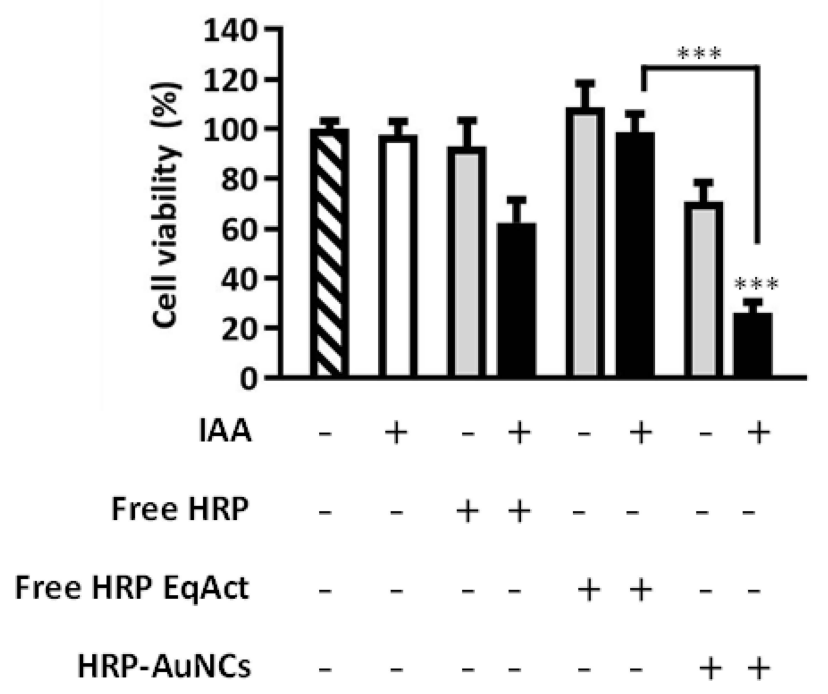

Figure 5 HRP-AuNCs for EPT in triple-negative breast cancer 3D tumour spheroid models. Cell viability assessment in MCTS formed by MDA-MB-23I cells incubated with HRP-AuNCs at $0.15 \mathrm{U} / \mathrm{mL}$ (equivalent to $1.62 \mu \mathrm{g}$ of HRP), free HRP EqAct at $0.15 \mathrm{U} / \mathrm{mL}$ (equivalent to $5.55 \times 10^{-7} \mu \mathrm{g}$ of HRP) or free HRP at $1.2 \mu \mathrm{g} / \mathrm{mL}$ (equivalent to $3.24 \times 10^{4} \mathrm{U} / \mathrm{mL}$ ) in the absence or presence of IAA at $250 \mu \mathrm{M}$. Cell viability was determined after $48 \mathrm{~h}$ of incubation by WST-I assay. Data represent means \pm SEM $(n=3)$. Significant differences were compared to control according to one-way ANOVA and Dunns post-test $(* * * p<0.001)$.

On the other hand, either free HRP EqAct $(0.15 \mathrm{U} / \mathrm{mL}$, equivalent to $5.55 \times 10^{-7} \mu \mathrm{g}$ of HRP $)$ or free HRP $(1.2 \mu \mathrm{g} /$ $\mathrm{mL}$, equivalent to $3.24 \times 10^{4} \mathrm{U} / \mathrm{mL}$ ) combined with IAA did not induce any significant effect on viability.

The obtained favorable data evidence that the use of HRP-AuNCs is a powerful strategy to expand the applications of enzyme prodrug therapy based on HRP/IAA system. The results obtained along the present work show AuNPs as a feasible scaffold for the development of novel nanodevices with advanced applications, as they possess several advantages including well-established, fast, and relative low-cost synthesis, easy stabilization by surface coating, and biocompatibility. In accordance with our results, previous studies with silica nanoparticles showed the ability of encapsulated HRP to transform IAA into free radicals to perform prodrug tumor therapy in $\operatorname{colon}^{83}$ and cervix cancer. ${ }^{84,85}$ Horseradish peroxidase has also been nanoformulated using polymeric chitosan nanoparticles to induce cell death in a breast cancer cellular model. ${ }^{86}$ Differential studies would shed light on the most appropriate nanoformulation for HRP in terms of reproducibility of synthesis, enzyme stability and activity, in vivo biodistribution, safety, antitumor efficacy, etc.

Currently, antibodies ${ }^{14,15}$ and viruses ${ }^{16,17}$ as enzyme vehicles are the most advanced in clinical trials.
However, these approaches do not completely accomplish the therapeutic needs. Their clinical application has been mainly hindered by the potential immunogenicity and the risk of mutation of the viral vectors. ${ }^{14,18}$ As a consequence, the development of novel abiotic enzyme nanocarriers are a promising alternative to advance enzyme prodrug therapy toward application in patients. Gold-based nanomaterials have not been approved for clinical use, but several clinical trials in early phases (ClinicalTrials.gov Identifier: NCT03020017, NCT01270139, NCT02837094, and NCT04081714) are studying their application for the treatment of cancer and other ailments. Further investigations would promote the incorporation of gold nanoparticles in cancer treatment, where enzyme prodrug therapy represent an encouraging strategy to increase the specificity and efficiency of conventional tumor therapies.

\section{Conclusion}

In summary, we report here the design, preparation, characterization, and evaluation of a nanodevice based on gold nanoparticles decorated with the enzyme horseradish peroxidase (HRP-AuNCs) to perform EPT in breast cancer cells. Gold conjugates are synthesized using gold nanoparticles as starting materials, which are first functionalized with 3-mercaptopropionic acid to yield (3-MPA)-AuNCs, which are further equipped with HRP (HRP-AuNCs). The proper formation and enzyme activity of the nanodevice are determined by TEM-EDX, UV-Vis spectrophotometry, FT-IR spectrometry, DLS, $\zeta$ potential, and peroxidase activity assays. Biocompatibility experiments demonstrate that HRP-AuNCs is well tolerated by breast cancer cell lines (i.e., luminal A and TN subtypes). Moreover, TEM visualization of both breast cancer cell treated with HRPAuNCs reveals that nanoparticles are successfully internalized and located in secondary lysosomes. Furthermore, the co-treatment with HRP-AuNCs and IAA efficiently triggers cell death induced by oxidative stress, whereas free HRP at the equivalent enzyme activity in combination with IAA have no effect. Moreover, a larger therapeutic effect is achieved with HRP-AuNCs compared with the free HRP used at the standard dose reported in the bibliography.

Taking together, these results demonstrate that HRP nanoformulation is a promising tool to boost the therapeutic effect of HRP/IAA enzyme prodrug system. The increased therapeutic effect reached with HRP-AuNCs could be explained because of the high internalization 
efficiency of the nanoconjugates by tumor cells and the localized ROS production within cells that leads to increased toxicity. Additionally, the conjugation of enzymes with gold nanoparticles, as previously proved, can improve enzyme stability and activity. The presented findings could help to bypass enzyme therapy limiting factors and help advance towards therapeutic applications including breast cancer treatment.

\section{Acknowledgments}

Gema Vivo-Llorca thanks the Generalitat Valenciana for her fellowship ACIF/2017/072. Paula Díez thanks the Generalitat Valenciana for her contract APOSTD/2020/153 and to the Instituto de Salud Carlos III and the European Social Fund for the financial support "Sara Borrell", CD20/00120. Antoni Llopis-Lorente thanks funding from the European Union's Horizon 2020 research and innovation programme under grant agreement No 847675. Images were prepared using Servier Medical Art (https://smart.servier.com/). We thank the Spanish Government (project RTI2018-100910-B-C41 (MCUI/AEI/FEDER, UE); SAF2017-84689-R-B (MCUI/ AEI/FEDER, UE)) and the Generalitat Valenciana (project PROMETEO/2018/024 and PROMETEO/2019/065) for support. A pre-print version of this work was published as a chapter of the PhD thesis of the first author Gema VivoLlorca.

\section{Disclosure}

The authors report no conflicts of interest in this work

\section{References}

1. Globocan. Estimated number of new cases in 2018, worldwide, all cancers, females, all ages. Glob Scan. 2018;849:2018.

2. Globocan. Estimated number of deaths in 2018, worldwide, all cancers, males, all ages. Glob Scan. 2018;947:2018.

3. Cardoso F, Kyriakides S, Ohno S, et al. Early breast cancer: ESMO Clinical Practice Guidelines for diagnosis, treatment and follow-up. Ann Oncol. 2019;30(8):1194-1220. doi:10.1093/annonc/mdz173

4. Partridge AH, Burstein HJ, Winer EP. Side effects of chemotherapy and combined chemohormonal therapy in women with early-stage breast cancer. J Natl Cancer Inst Monogr. 2001;334(30):135-142. doi:10.1093/oxfordjournals.jncimonographs.a003451

5. Maeda H. The tumor blood vessel as an ideal target for macromolecular anticancer agents. J Control Release. 1992;19(1-3):315-324. doi:10.1016/0168-3659(92)90086-7

6. Matsumura Y, Maeda H, New A. Concept for macromolecular therapeutics in cancer chemotherapy: mechanism of tumoritropic accumulation of proteins and the antitumor agent smancs. Cancer Res. 1986;46(8):6387-6392.

7. Sarkar S, Konar S, Prasad PN, et al. Micellear gold nanoparticles as delivery vehicles for dual tyrosine kinase inhibitor ZD6474 for metastatic breast cancer treatment. Langmuir. 2017;33(31):7649-7659. doi:10.1021/acs.langmuir.7b01072
8. Tran P, Lee S-E, Kim D-H, Pyo Y-C, Park J-S. Recent advances of nanotechnology for the delivery of anticancer drugs for breast cancer treatment. J Pharm Investig. 2020;50(3):261-270. doi:10.1007/ s40005-019-00459-7

9. Ensor CM, Holtsberg FW, Bomalaski JS, Clark MA. Pegylated arginine deiminase (ADI-SS PEG20,000 mw) inhibits human melanomas and hepatocellular carcinomas in vitro and in vivo. Cancer Res. 2002;62(19):5443-5450.

10. Avramis VI, Sencer S, Periclou AP, et al. A randomized comparison of native Escherichia coli asparaginase and polyethylene glycol conjugated asparaginase for treatment of children with newly diagnosed standard-risk acute lymphoblastic leukemia: a Children's Cancer Group study. Blood. 2002;99(6):1986-1994. doi:10.1182/blood. v99.6.1986

11. Schellmann N, Deckert PM, Bachran D, Fuchs H, Bachran C. Targeted enzyme prodrug therapies. Mini Rev Med Chem. 2010;10 (10):887-904. doi:10.2174/138955710792007196

12. Xu G, Mcleod HL. Strategies for enzyme/prodrug cancer therapy. Clin Cancer Res. 2001;7:3314-3324.

13. Sharma SK, Bagshawe KD, Melton RG, Sherwood RF. Human immune response to monoclonal antibody-enzyme conjugates in ADEPT pilot clinical trial. Cell Biophys. 1992;21(1-3):109-120. doi:10.1007/BF02789482

14. Francis RJ, Sharma SK, Springer C, et al. A Phase I trial of antibody directed enzyme prodrug therapy (ADEPT) in patients with advanced colorectal carcinoma or other CEA producing tumours. Br J Cancer. 2002;87(6):600-607. doi:10.1038/sj.bjc.6600517

15. Mayer A, Francis RJ, Sharma SK, et al. A Phase I study of single administration of antibody-directed enzyme prodrug therapy with the recombinant anti-carcinoembryonic antigen antibody-enzyme fusion protein MFECP1 and a bis-iodo phenol mustard prodrug. Clin Cancer Res. 2006;12(21):6509LP- 6516. doi:10.1158/1078-0432. CCR-06-0769

16. Cloughesy TF, Landolfi J, Hogan DJ, et al. Phase 1 trial of vocimagene amiretrorepvec and 5-fluorocytosine for recurrent high-grade glioma. Sci Transl Med. 2016;8(341):1-23. doi:10.1126/scitranslmed.aad 9784

17. Ji N, Weng D, Liu C, et al. Adenovirus-mediated delivery of herpes simplex virus thymidine kinase administration improves outcome of recurrent high-grade glioma. Oncotarget. 2016;7(4):4369-4378. doi:10.18632/oncotarget.6737

18. Niculescu-Duvaz I, Spooner R, Marais R, Springer CJ. Gene-directed enzyme prodrug therapy. Bioconjug Chem. 1998;9(1):4-22. doi:10.1021/bc970116t

19. Huysmans G, Ranquin A, Wyns L, Steyaert J, Van Gelder P. Encapsulation of therapeutic nucleoside hydrolase in functionalised nanocapsules. J Control Release. 2005;102(1):171-179. doi:10.1016/ j.jconrel.2004.10.002

20. Chandrawati R, Olesen MTJ, Marini TCC, et al. Enzyme prodrug therapy engineered into electrospun fibers with embedded liposomes for controlled, localized synthesis of therapeutics. Adv Healthc Mater. 2017;6(17):1700385. doi:10.1002/adhm.201700385

21. Satchi-Fainaro R, Hailu H, Davies JW, Summerford C, Duncan R. PDEPT: polymer-directed enzyme prodrug therapy. 2. HPMA Copolymer- $\beta$-lactamase and HPMA Copolymer-C-Dox as a model combination. Bioconjug Chem. 2003;14(4):797-804. doi:10.1021/bc020091k

22. Nishimura T, Sasaki Y, Akiyoshi K. Biotransporting self-assembled nanofactories using polymer vesicles with molecular permeability for enzyme prodrug cancer therapy. Adv Mater. 2017;29(36):1702406. doi:10.1002/adma.201702406

23. Gupta N, Gupta C, Sharma S, Rathi B, Sharma RK, Bohidar HB. Magnetic iron oxide nanoparticles encapsulating horseradish peroxidase (HRP): synthesis, characterization and carrier for the generation of free radicals for potential applications in cancer therapy. RSC $A d v$. 2016;6(112):111099-111108. doi:10.1039/C6RA24586B 
24. Zhou J, Hou J, Rao J, Zhou C, Liu Y, Gao W. Magnetically directed enzyme/prodrug prostate cancer therapy based on $\beta$-Glucosidase /Amygdalin. Int J Nanomedicine. 2020;15:4639-4657. doi:10.2147/ IJN.S242359

25. Llopis-Lorente A, Garciá-Fernández A, Murillo-Cremaes $\mathrm{N}$, et al. Enzyme-powered gated mesoporous silica nanomotors for on-command intracellular payload delivery. ACS Nano. 2019;13 (10):12171-12183. doi:10.1021/acsnano.9b06706

26. Llopis-Lorente A, de Luis B, García-Fernández A, et al. AuMesoporous silica nanoparticles gated with disulfide-linked oligo (ethylene glycol) chains for tunable cargo delivery mediated by an integrated enzymatic control unit. J Mater Chem B. 2017;5 (33):6734-6739. doi:10.1039/C7TB02045G

27. Wang Z, Chen L, Chu Z, Huang C, Huang Y, Jia N. Gemcitabineloaded gold nanospheres mediated by albumin for enhanced anti-tumor activity combining with CT imaging. Mater Sci Eng C. 2018;89:106-118. doi:10.1016/j.msec.2018.03.025

28. Iranpour P, Ajamian M, Safavi A, Iranpoor N, Abbaspour A, Javanmardi S. Synthesis of highly stable and biocompatible gold nanoparticles for use as a new X-ray contrast agent. J Mater Sci Mater Med. 2018;29(5):48. doi:10.1007/s10856-018-6053-5

29. Ghahremani F, Kefayat A, Shahbazi-Gahrouei D, Motaghi H, Mehrgardi MA, Haghjooy-Javanmard S. AS1411 aptamer-targeted gold nanoclusters effect on the enhancement of radiation therapy efficacy in breast tumor-bearing mice. Nanomedicine. 2018;13 (20):2563-2578. doi:10.2217/nnm-2018-0180

30. Bailly AL, Correard F, Popov A, et al. In vivo evaluation of safety, biodistribution and pharmacokinetics of laser-synthesized gold nanoparticles. Sci Rep. 2019;9(1):1-12. doi:10.1038/s41598-01948748-3

31. Brust M, Walker M, Bethell D, Schiffrin DJ, Whyman R. Synthesis of thiol-derivatised gold nanoparticles in a two-phase Liquid-Liquid system. J Chem Soc Chem Commun. 1994;(7):801-802. doi:10.1039/ C39940000801

32. Jana NR, Gearheart L, Murphy CJ. Seeding growth for size control of 5-40 nm diameter gold nanoparticles. Langmuir. 2001;17 (22):6782-6786. doi:10.1021/1a0104323

33. Perrault SD, Chan WCW. Synthesis and surface modification of highly monodispersed, spherical gold nanoparticles of 50-200 nm. J Am Chem Soc. 2009;131(47):17042-17043. doi:10.1021/ja907069u

34. Grzelczak M, Pérez-Juste J, Mulvaney P, Liz-Marzán LM. Shape control in gold nanoparticle synthesis. Chem Soc Rev. 2008;37 (9):1783-1791. doi:10.1039/b711490g

35. Pérez-Calabuig AM, Díez P, Martínez-Ruiz P, Martínez-Máñez R, Sánchez A, Villalonga R. An enzyme-controlled Janus nanomachine for on-command dual and sequential release. Chem Commun. 2020;56(47):6440-6443. doi:10.1039/D0CC01234C

36. Akbarzadeh Khiavi M, Safary A, Aghanejad A, et al. Enzymeconjugated gold nanoparticles for combined enzyme and photothermal therapy of colon cancer cells. Colloids Surfaces a Physicochem Eng Asp. 2019;572:333-344. doi:10.1016/j.colsurfa.2019.04.019

37. Sendra L, Miguel A, Navarro-Plaza MC, et al. Gold nanoparticle-assisted virus formation by means of the delivery of an oncolytic adenovirus genome. Nanomater. 2020;10(6):1183. doi:10.3390/nano10061183

38. Ramchandani D, Lee SK, Yomtoubian S, Han MS, Tung C-H, Mittal V. Nanoparticle delivery of miR-708 mimetic impairs breast cancer metastasis. Mol Cancer Ther. 2019;18(3):579 LP- 591. doi:10.1158/1535-7163.MCT-18-0702

39. Liu Y, Yang M, Zhang J, et al. Human induced pluripotent stem cells for tumor targeted delivery of gold nanorods and enhanced photothermal therapy. ACS Nano. 2016;10(2):2375-2385. doi:10.1021/ acsnano. 5 b0 07172
40. Cai Z, Chattopadhyay N, Yang K, et al. 111In-labeled trastuzumab-modified gold nanoparticles are cytotoxic in vitro to HER2-positive breast cancer cells and arrest tumor growth in vivo in athymic mice after intratumoral injection. Nucl Med Biol. 2016;43 (12):818-826. doi:10.1016/j.nucmedbio.2016.08.009

41. Abdolahinia ED, Nadri S, Rahbarghazi R, Barar J, Aghanejad A, Omidi Y. Enhanced penetration and cytotoxicity of metformin and collagenase conjugated gold nanoparticles in breast cancer spheroids. Life Sci. 2019;231:116545. doi:10.1016/j.1fs.2019.116545

42. Dreaden EC, Mwakwari SC, Sodji QH, Oyelere AK, El-Sayed MA. Tamoxifen-Poly(ethylene glycol)-thiol gold nanoparticle conjugates: enhanced potency and selective delivery for breast cancer treatment. Bioconjug Chem. 2009;20(12):2247-2253. doi:10.1021/bc9002212

43. Hernández Montoto A, Montes R, Samadi A, et al. Gold nanostars coated with mesoporous silica are effective and nontoxic photothermal agents capable of gate keeping and laser-induced drug release. ACS Appl Mater Interfaces. 2018;10(33):27644-27656. doi:10.1021/ acsami.8b08395

44. Hernández Montoto A, Llopis-Lorente A, Gorbe M, et al. Janus gold nanostars-mesoporous silica nanoparticles for NIR-light-triggered drug delivery. Chem - a Eur J. 2019;25(36):8471-8478. doi:10.1002/chem. 201900750

45. de Luis B, Morellá-Aucejo Á, Llopis-Lorente A, et al. A chemical circular communication network at the nanoscale. Chem Sci. 2021;12 (4):1551-1559. doi:10.1039/D0SC04743K

46. de Luis B, Llopis-Lorente A, Rincón P, et al. An interactive model of communication between abiotic nanodevices and microorganisms. Angew Chemie Int Ed. 2019;58(42):14986-14990. doi:10.1002/ anie. 201908867

47. Llopis-Lorente A, Díez P, Sánchez A, et al. Interactive models of communication at the nanoscale using nanoparticles that talk to one another. Nat Commun. 2017;8:15511. doi:10.1038/ncomms 15511

48. Li D, He Q, Cui Y, Duan L, Li J. Immobilization of glucose oxidase onto gold nanoparticles with enhanced thermostability. Biochem Biophys Res Commun. 2007;355(2):488-493. doi:10.1016/j. bbrc.2007.01.183

49. Shikha S, Thakur KG, Bhattacharyya MS. Facile fabrication of lipase to amine functionalized gold nanoparticles to enhance stability and activity. RSC Adv. 2017;7(68):42845-42855. doi:10.1039/ C7RA06075K

50. Wu C-S, Wu C-T, Yang Y-S, Ko F-H. An enzymatic kinetics investigation into the significantly enhanced activity of functionalized gold nanoparticles. Chem Commun. 2008;(42):5327-5329. doi:10.1039/ B810889G

51. Lan D, Li B, Zhang Z. Chemiluminescence flow biosensor for glucose based on gold nanoparticle-enhanced activities of glucose oxidase and horseradish peroxidase. Biosens Bioelectron. 2008;24 (4):934-938. doi:10.1016/j.bios.2008.07.064

52. Veitch NC. Horseradish peroxidase: a modern view of a classic enzyme. Phytochemistry. 2004;65(3):249-259. doi:10.1016/j. phytochem.2003.10.022

53. Krainer FW, Glieder A. An updated view on horseradish peroxidases: recombinant production and biotechnological applications. Appl Microbiol Biotechnol. 2015;99(4):1611-1625. doi:10.1007/s00253014-6346-7

54. Bonifert G, Folkes L, Gmeiner C, Dachs G, Spadiut O. Recombinant horseradish peroxidase variants for targeted cancer treatment. Cancer Med. 2016;5(6):1194-1203. doi:10.1002/cam4.668

55. Tupper J, Greco O, Tozer GM, Dachs GU. Analysis of the horseradish peroxidase/indole-3-acetic acid combination in a three dimensional tumor model. Cancer Gene Ther. 2004;11(7):508-513. doi:10.1038/sj.cgt.7700713 
56. Dai M, Liu J, Chen DE, et al. Tumor-targeted gene therapy using Adv-AFP-HRPC/IAA prodrug system suppresses growth of hepatoma xenografted in mice. Cancer Gene Ther. 2012;19(2):77-83. doi: $10.1038 /$ cgt.2011.65

57. Tupper J, Stratford MR, Hill S, Tozer GM, Dachs GU. In vivo characterization of horseradish peroxidase with indole-3-acetic acid and 5-bromoindole-3-acetic acid for gene therapy of cancer. Cancer Gene Ther. 2010;17(6):420-428. doi:10.1038/cgt.2009.86

58. Bennett MJ, Marchant A, May ST, Swarup R. Going the distance with auxin: unravelling the molecular basis of auxin transport. Philos Trans R Soc B Biol Sci. 1998;353(1374):1511-1515. doi:10.1098/ rstb.1998.0306

59. Diengott I-AM, Diengott D. Hypoglycemic action of indole-3-acetic acid by mouth in patients with diabetes mellitus. Proc Soc Exp Biol Med. 1956;93(1):109-110. doi:10.3181/00379727-93-22678

60. Ryšánek K, Vítek V. Increased excretion of 5-hydroxy-indole-acetic acid after the administration of 3-indole-acetic acid (heteroauxine). Experientia. 1959;15(6):217-218. doi:10.1007/BF02158112

61. Kim D-S, Kim S-Y, Jeong Y-M, et al. Indole-3-acetic acid/horseradish peroxidase-induced apoptosis involves cell surface CD95 (Fas/ APO-1) expression. Biol \& Pharm Bull. 2006;29(8):1625-1629. doi:10.1248/bpb.29.1625

62. Jeong YM, Oh MH, Kim SY, et al. Indole-3-acetic acid/horseradish peroxidase induces apoptosis in TCCSUP human urinary bladder carcinoma cells. Pharmazie. 2010;65(2):122-126. doi:10.1691/ ph.2010.9715

63. Turkevich J, Stevenson PC, Hillier J. A study of the nucleation and growth processes in the synthesis of colloidal gold. Discuss Faraday Soc. 1951;11:55-75. doi:10.1039/DF9511100055

64. Frens G. Controlled nucleation for the regulation of the particle size in monodisperse gold suspensions. Nat Phys Sci. 1973;241 (105):20-22. doi:10.1038/physci241020a0

65. Keesey J. Biochemica Information. In: Biochemica Information. Boehringer Mannheim Biochemicals; 1987:58.

66. Pütter J, Becker R. Methods of enzymatic analysis. Bergmeyer H-UI, editor. Methods of Enzymatic Analysis. $3^{\text {rd }}$ ed. Vol. III: Verlag Chemie; 1974:286-293.

67. Friedrich J, Seidel C, Ebner R, Kunz-Schughart LA. Spheroid-based drug screen: considerations and practical approach. Nat Protoc. 2009;4(3):309-324. doi:10.1038/nprot.2008.226

68. Ivascu A, Kubbies M. Rapid generation of single-tumor spheroids for high-throughput cell function and toxicity analysis. J Biomol Screen. 2006;11(8):922-932. doi:10.1177/1087057106292763

69. Kim D-S, Jeon S-E, Jeong Y-M, Kim S-Y, Kwon S-B, Park K-C. Hydrogen peroxide is a mediator of indole-3-acetic acid/horseradish peroxidase-induced apoptosis. FEBS Lett. 2006;580(5):1439-1446. doi:10.1016/j.febslet.2006.01.073

70. Kim DS, Jeon SE, Park KC. Oxidation of indole-3-acetic acid by horseradish peroxidase induces apoptosis in G361 human melanoma cells. Cell Signal. 2004;16(1):81-88. doi:10.1016/S0898-6568(03) 00091-3

71. Rodrigues RC, Ortiz C, Berenguer-Murcia Á, Torres R, FernándezLafuente R. Modifying enzyme activity and selectivity by immobilization. Chem Soc Rev. 2013;42(15):6290-6307. doi:10.1039/c2cs35231a

International Journal of Nanomedicine

\section{Publish your work in this journal}

The International Journal of Nanomedicine is an international, peerreviewed journal focusing on the application of nanotechnology in diagnostics, therapeutics, and drug delivery systems throughout the biomedical field. This journal is indexed on PubMed Central, MedLine, CAS, SciSearch ${ }^{\mathbb{R}}$, Current Contents ${ }^{\mathbb{R}} /$ Clinical Medicine, $^{2}$
72. Kang T, Kim YG, Kim D, Hyeon T. Inorganic nanoparticles with enzyme-mimetic activities for biomedical applications. Coord Chem Rev. 2020;403:213092. doi:10.1016/j.ccr.2019.213092

73. Wang S, Chen W, Liu A-L, Hong L, Deng -H-H, Lin X-H. Comparison of the peroxidase-like activity of unmodified, amino-modified, and citrate-capped gold nanoparticles. Chemphyschem. 2012;13 (5):1199-1204. doi:10.1002/cphc.201100906

74. Gao L, Liu M, Ma G, et al. Peptide-conjugated gold nanoprobe: intrinsic nanozyme-linked immunsorbant assay of integrin expression level on cell membrane. ACS Nano. 2015;9(11):10979-10990. doi:10.1021/acsnano.5b04261

75. Lou D, Tian Y, Zhang Y, et al. Peroxidase-like activity of gold nanoparticles and their gold staining enhanced ELISA application. J Nanosci Nanotechnol. 2018;18(2):951-958. doi:10.1166/jnn.2018. 13977

76. Reis-Filho JS, Pusztai L. Gene expression profiling in breast cancer: classification, prognostication, and prediction. Lancet. 2011;378 (9805):1812-1823. doi:10.1016/S0140-6736(11)61539-0

77. Balfourier A, Luciani N, Wang G, et al. Unexpected intracellular biodegradation and recrystallization of gold nanoparticles. Proc Natl Acad Sci U S A. 2020;117(1):103-113. doi:10.1073/pnas.1911734116

78. Yan X, Blacklock J, Li J, Möhwald H. One-pot synthesis of polypeptide-gold nanoconjugates for in vitro gene transfection. ACS Nano. 2012;6(1):111-117. doi:10.1021/nn202939s

79. Mukherjee S, Dasari M, Priyamvada S, Kotcherlakota R, Bollu VS, Patra CR. A green chemistry approach for the synthesis of gold nanoconjugates that induce the inhibition of cancer cell proliferation through induction of oxidative stress and their in vivo toxicity study. J Mater Chem B. 2015;3(18):3820-3830. doi:10.1039/C5TB00244C

80. Poulsen AK, Scharff-Poulsen AM, Olsen LF. Horseradish peroxidase embedded in polyacrylamide nanoparticles enables optical detection of reactive oxygen species. Anal Biochem. 2007;366(1):29-36. doi:10.1016/j.ab.2007.04.004

81. Sohrabi N, Rasouli N, Torkzadeh M. Enhanced stability and catalytic activity of immobilized $\alpha$-amylase on modified $\mathrm{Fe} 3 \mathrm{O} 4$ nanoparticles. Chem Eng J. 2014;240:426-433. doi:10.1016/j.cej.2013.11.059

82. Lu H, Stenzel MH. Multicellular tumor spheroids (MCTS) as a 3D in vitro evaluation tool of nanoparticles. Small. 2018;14 (13):1702858. doi:10.1002/smll.201702858

83. Hung BY, Kuthati Y, Kankala RK, et al. Utilization of enzyme-immobilized mesoporous silica nanocontainers (IBN-4) in prodrug-activated cancer theranostics. Nanomaterials. 2015;5 (4):2169-2191. doi:10.3390/nano5042169

84. Chang F-P, Hung Y, Chang J-H, Lin C-H, Mou C-Y. Enzyme encapsulated hollow silica nanospheres for intracellular biocatalysis. $A C S$ Appl Mater Interfaces. 2014;6(9):6883-6890. doi:10.1021/ am500701c

85. Chiu Y-R, Ho W-J, Chao J-S, Yuan C-J. Enzyme-encapsulated silica nanoparticle for cancer chemotherapy. J Nanoparticle Res. 2012;14 (4):829. doi:10.1007/s11051-012-0829-1

86. Cao X, Chen C, Yu H, Wang P. Horseradish peroxidase-encapsulated chitosan nanoparticles for enzyme-prodrug cancer therapy. Biotechnol Lett. 2015;37(1):81-88. doi:10.1007/s10529-014-1664-5
Journal Citation Reports/Science Edition, EMBase, Scopus and the Elsevier Bibliographic databases. The manuscript management system is completely online and includes a very quick and fair peer-review system, which is all easy to use. Visit http://www.dovepress.com/ testimonials.php to read real quotes from published authors. 